\title{
COMMUNITY AND SOCIAL CONTROL DURING THE COVID-19 PANDEMIC
}

\author{
Mihai PASCARU 1 \\ DOI: https://doi.org/10.35782/JCPP.2021.3.01
}

\begin{abstract}
Revealing an increase in interest for the community as a result of the COVID-19 pandemic, the paper starts with a succinct compilation of the main practical and theoretical contexts in which the concept has been revitalized during the past year: World Health Organization's guidelines, several SARS-Cov-2 disease control actions, studies of racial and ethnic diversity inequalities and studies of psycho-sociological impact of the pandemic. Next, some basic mechanisms notions are analyzed in regard to informal social control. The results from a research survey that took place between November $26^{\text {th }} 2020$ and January $26^{\text {th }} 2021$ on a lot of 1640 respondents revealed the existence of an optimism-generating base in regard to the community-level informal social control during special situations like the COVID-19 pandemic. Even if some socio-demographic variables like gender, age and type of community, or some personal experience with COVID-19 variables like personal infection, family loss and neighborhood loss do not significantly associate with the acceptance of collective restrictions, it is our appreciation that there are premises for launching informal social control stimulation community interventions by empowerment or by community development.
\end{abstract}

Keywords: community, social control, COVID-19, empowerment

\section{Introduction}

Notwithstanding its impact on medical science, the COVID-19 pandemic also had an indisputably significant impact on social science. Here, the effect of bringing the notion of community back into the foreground represents a fact that is remarkable in its theoretical and practical immediate and long-term consequences. In association with the notion of community, the practices of social control in general and that of informal social control in particular have also been frequently invoked during the past year, albeit less insistently and with less scientific consistency than the notion of community.

Emerging from epidemiology, the term "community spreading" was the first term to impose on our attention the view of community more so as a threat than as a beneficial environment. This happened during the initial period of the pandemic in which the Italian doctors from Bergamo were claiming that in a pandemic, the "patient-centered

1 PhD Professor, “1 Decembrie 1918” University of Alba Iulia, Department of Social Sciences, e-mail: mihaipascarupag@gmail.com 
care adopted by western healthcare systems is inadequate and must be replaced by community-centered care" (Sakellarides, 2020, p. 1). The World Health Organization had invoked even as of March 19th, 2020 the need for the presence of community engagement in the pandemic information campaigns from previous week. With this occasion one was establishing the need for a better understanding of the feelings, the attitudes and the behavior of community members and the promotion of a proactive and interactive information effort with the wide participation of mass media (World Health Organization, 2020, p. 2). In practice, in the 14 million inhabitant metropolis of Wuhan, China, the panic, the rumors and the rapid spread of the disease determined the commissioning of a Community Governance Systems institution aimed at the identification of community needs, the implementation of isolation strategies and the increase in local community involvement mentioned by World Health Organization (Zhu and Cai, 2020, p.1).

Drawing attention to such important aspects of community role in dealing with the pandemic from the very beginning of it, the present paper will start with a summary of the past year's themes that linked the community with the spread and control of COVID-19, ranging from the indigenous communities' perspective on voluntary isolation and through the inequalities and diversity of the large American metropolitan communities. The pandemic's psycho-sociological impact at community level will not be ignored either.

In the second part of the paper, we will consider some aspects of social control in general and that of informal community social control in particular. We will be doing this in order to provide a stronger foundation for the analysis of some results provided by a recently undertaken survey. These results refer to subjective determinants of informal social control in the community (or urban neighborhood). The informal community control is seen from the perspective of compliance with the COVID-19 disease control measures. The above-mentioned results will then be succinctly presented in the third section of the article. The discussion of these results from the last part of the paper is also integrated with a series of more general considerations of the need for implication, participation and community development - another important theme of the last years' social science and practice.

The conclusions of the article underline a greater significance of its issues appearing under the perspective of the changes that are to be expected to take shape beyond communities' borders, in the integrator social system.

\section{The Notion of Community in COVID-19 Disease Control Research Studies}

\subsection{Social Inequalities and the Spread of the Virus in the Communities}

The issues of social inequality and of diversity within and between the communities appear to dominate the current literature on community roots and spread of the SARS-CoV-2 virus analysis. 
In this context, a series of works have been dedicated to indigenous communities. Kaplan and his colleagues reminded us that 370 million indigenous people reside in almost 90 countries and make up for almost $5 \%$ of world population (Kaplan, Trumble, Stieglitz, Mendez Mamany, Gutierrez Cayuba, Maito Moye, Alami, Kraft, Quispe Gutierrez, Copajira Adrian, Thompson, Thomas, Michalik, Rodriguez, and Gurven, 2020, p. 1729). The indigenous populations are some of the most vulnerable, the authors contend, due to their style of residence in large families, to their work in common habits, to their sharing of food, and to their other group-oriented activities. For these communities, the traditional solution is their voluntary collective isolation far from foreigners and sometimes deep in the jungle (Kaplan et al., 2020, p. 1729).

Other studies examined the differences between rural and urban areas as to the intermediation of the COVID-19 spread and community relationship. In Canada for example, the rural communities - Erwin emphasizes, contain the poorest population by comparison to urban and sub-urban areas, rural areas suffering also of the "historical mistrust of government" which create barriers to healthcare (Erwin, Aultman, Harter, Illes, and Rabbi Kogan, 2020, p. 1). In the United States, in depicting a map of community vulnerabilities and resilience, Peters underscored the fact that around $30 \%$ of the rural American communities were highly susceptible to COVID virus due to precarious health condition and to the inadequate facilities for older people. Other major vulnerabilities in rural areas included the insufficient number of physicians, the lack of mental health services, the large number of people with disabilities and a larger number of people without insurance. Poor access to telemedicine was also noted. The lack of social capital and of social services Peters appreciated, created a stumbling block to effective local disease control (Peters, 2020, p. 446).

Studies of large populations from urbanized areas take in account variables like social capital, social inequality and ethnic and racial diversity in order to explain variations in virus contagion rates at community level. In large communities like American counties researchers found that areas with high levels of social capital "may have been especially at risk during the early phases of the COVID-19 pandemic due to high levels of social interaction, but, at the same time, "norms of trust and reciprocity could have contributed to reducing the health impact of the pandemic" (Borgonovi, Andrieu and Subramanian, 2020, p. 1).

A series of studies made in New York concluded that in communities affected by poverty and scarce access to health and education, one can identify higher rates of diabetes, obesity and hypertension, the proportion of these chronic illnesses being larger in the communities more severely affected by COVID-19 (Harlem, 2020, p. 468).

In the United States, a number of problems emerged in immigrant communities. A study done by Center and colleagues revealed the fact that in the provinces of Benton and Washington, Arkansas while the Marshallese and Hispanic/Latino group made up $19 \%$ of the population, it was responsible for $64 \%$ of contagions and $57 \%$ of deaths from COVID-19 (Center, Da Silva, Hernandez Vang, Martin, Mazurek, Lilo, Zimmerman, Krow-Lucal, Campbell, Cowins, Walker, Dominguez, Gallo, Gunn, McCormick, Cochran, Smith, Dillaha, and James, 2020, p. 1807). Several reasons were invoked: 1) the limited use of their native language in public awareness messages; 2) the 
overcrowding of living spaces; 3) a high rate of employment in the chicken diary industry; 4) a lack of trust in the medical system; 5) the instability of COVID-19 recommendations (Center et al., 2020, p. 1807).

The intra- and inter-community inequalities impact being delineated, one should retain an important warning: "In all likelihood, COVID-19 will exacerbate existing inequalities, both in its immediate consequences resulting from the drastic measures taken to contain its spread, as well as its potential long-term consequences" (Fisher, Languilaire, Lawthom, Nieuwenhuis, Petts, Runswick-Cole, and Yerkes, 2020, p. 247).

\subsection{The Psycho-Social Impact on the Community}

Notwithstanding the physical burden placed on patients and health system, Dubey wrote, COVID-19 also has an enormous psycho-social impact (Dubey, Biswas, Ghosh, Chatterjee, Dubey, Chatterjee, Lahiri, and Lavie, 2020, p. 779). At the community level, the emergence of racism, stigmatization and xenophobia have frequently been reported and according to the same author, all of them being fuelled by an "infodemic" propagated through social networks (Dubey et al., 2020, p. 779). One set of examples mentioned by Chopra and Arora was that of a boycott of Chinese restaurants in Italy and of school classrooms where children of Chinese ancestry were studying (Chopra and Arora, 2020, p. 284). The same authors consider that such stigma can actually amplify the community effects of a disease by making the targets of stigmatization less likely to seek medical assistance and, by delaying treatment (or worse - avoiding it altogether), contributing to a rise in morbidity and mortality rates. Further on, the stigma and discrimination may contribute to a reduction of social capital through the exacerbation of existing inequalities and may create new forms of social division, subverting the community social matrix and raising roadblocks to disease control attempts (Chopra and Arora, 2020, p. 285).

While discussing COVID-19 impact on marginalized communities, Sneed and collaborators introduced the term "traumatized communities", particularly in reference to some Afro-American communities in The United States (Sneed, Key, Bailey, and Johnson-Lawrence, 2020, p. 447). A series of studies, according to Sneed and colleagues, showed that the level of fear of COVID-19 among Afro-Americas was almost twice as high as that of whites, being, in addition to that, associated with a fear of discrimination in access to medical services. The already high mortality rates of blacks were also doubled by the impossibility to organize community burial rituals that had a special role in coping with the loss of someone dear (Sneed et al., 2020, p. 447).

\section{Sport as a repository of moral values}

There are several notions that reference the idea of informal social control in the community. Vélez mentioned at one point the "public social control" which refers to "the ability of neighborhoods to solicit and secure external resources by establishing ties between neighborhoods and local governmental officials and police departments" (Vélez, 2001, p. 858). Within the same context one uses the expression "community social control" in reference to "the ability of a community to regulate itself by regulating the behavior of residents and visitor” (Vélez, 2001, p. 839). 
Part of the literature on the subject are some very successful studies of the ways the informal social control can contribute to the reduction in crime rates in urban areas. Some research on the matter revealed the fact that social relationships have a powerful significance in terms of social control (Warner and Rountree, 1997, p. 250) and Wickes and his colleagues have reached an important conclusion: "Residents with strong ties are more likely to engage in public and parochial informal social control actions than those individuals who lack social ties" (Wickes, Hipp, Sargeant, and Mazerolle, 2016, p. 101). Burchfield examined the connection between attachment and informal social control, the latter being defined as "the willingness of neighborhood residents to intervene in local problems" (Burchfield, 2009, p. 45). The research undertaken by Burchfield in Chicago neighborhoods concluded that the informal social control at neighborhood level was reliant on attitudinal attachment, that is to residents' feelings towards the neighborhood (Burchfield, 2009, p. 45). Based on the same studies Silver and Miller remarked that next to community attachment, the satisfaction with the police work was also a significant contributor to the informal social control (Silver and Miller, 2006, p. 551). Hence the need that the efforts to increase the level of informal social control in the neighborhoods to be focused "on improving police-community relations and local conditions that would lead residents to develop stronger attachments to their neighborhoods" (Silver and Miller, 2006, pp. 557-558).

In connection to the pandemic, an Australian lockdown survey with 1595 residents revealed the fact that the perception of effectiveness in COVID-19 police control was having a positive impact on the availability of citizens to intervene where some were breaking the restrictions (Sargeant, Murphy, McCarthy, and Williamson, 2021, p. 1). These results - Sanders and collaborators appreciated - "suggest that, in the face of challenging times that disrupt norms for public behavior, police play an important role in norm-setting and facilitating informal social control behaviors in the community" (Sargeant et al., 2021, p. 17).

An article signed by Gabriel and others debated the role of power in the social control of vulnerable youth during COVID-19 pandemic. The significance of this study is more general in relation to the subject here - social control in the community. The author elicits one to ask oneself questions like How much social control?, Who controls?, and What is the status of the controlled? Gabriel and colleagues criticized for instance the adultism that was promoted during the pandemic and those actions "empowering vulnerable youth to take the lead to activate change in their community rather than be oppressed by the current inequitable systems, policies, and practices" (Gabriel et al., 2020, p. 6).

\section{The Informal Social Control in Community during the COVID-19 Pandemic}

\subsection{The Method and the Sample}

Our research study is based on a survey that was undertaken between November 6th, 2020 and January 26th, 2021, period in which, in Romania, the contamination peaked. The respondents have been contacted directly via Facebook and indirectly by our 
students and other collaborators on the same social network. Partial data from November 6th through December 19th, 2020 has been made public previously (Pascaru, 2021). The main issues were fears, attitudes towards restrictive measures, quality of life, and trust and tolerance; we will only be focusing here on those pertaining to social control and the restrictions on collective manifestations that can implicate the community.

As of January 26th, 2021, the sample of respondents who answered was of 1640 persons. We will be presenting further only those sample characteristics that will make up independent variables. Firstly, one should retain the gender breakdown of 639 $(39 \%)$ males, $994(60.6 \%)$ females, and $7(0.4 \%)$ undeclared; secondly the age profile involved 625 persons $(38.1 \%)$ between 18 and 29 years old, 336 persons $(20.5 \%)$ between 30 and 39, $319(19.5 \%)$ between 40 and 49, $194(11.8 \%)$ between 50 and 59, $115(7 \%)$ between 60 and 69 , and finally 45 persons $(2.7 \%)$ of 70 and over years of age; 6 respondents $(0.4 \%)$ did not declare their age. Most subjects (1211 or $73.8 \%$ ) were living in an urban community during the pandemic, 418 or $25.5 \%$ in a rural one and 11 $(0.7 \%)$ did not declare. The rates of undeclared as to gender, age and place of residence may be attributed to the sensitive nature of the subject.

Other features of the sample have to do with the experience of COVID-19 (infections, infections of persons that were close, and deceased that were close). Again, one will retain here only those features associated with the data analysis. One should thus retain that 137 respondents $(8.4 \%)$ declared having been infected, $1167(71.2 \%)$ having not been infected and $326(19.9 \%)$ not knowing having been infected or not. Ten respondents $(0.6 \%)$ did not answer. Out of all participants $78(4.8 \%)$ declared having family members and close relatives deceased because of COVID-19 and 1546 or $94.3 \%$ not having; 16 persons $(1 \%)$ did not answer on this issue. As to having neighbors deceased as a result of COVID-19 contamination, 335 (20.4\% declared having them, $1276(77.8 \%)$ not having them, with 29 respondents $(1.8 \%)$ refusing any declaration. The non-responses, again should be interpreted as having to do with the sensitivity of the subject. Beyond that, all characteristics will be treated as independent variables.

\subsection{Results}

The first issue of interest to us is that of respondents' perception of the existence of the informal social control exercised by the community (village/neighborhood) to which they belong.

A number of 387 respondents, or $23.6 \%$ appreciated that the village/neighborhood controls its members life to a large extent, 617 or $37 \%$ in a small measure and 439 $(26 \%)$ to no measure at all; $197(12 \%)$ did not know or did not answer.

As to the most frequent life aspect being controlled, most (723 or 44.1\%) opinionated to be the abidance by the law, 286 or $17.4 \%$ though to be the behavior of one to another, and $63(3.8 \%)$ to be the respect for tradition; 387 or $23.6 \%$ thought there is no control whatsoever and $181(11 \%)$ did not know/did not answer.

A second point of interest for our study is that of the level of involvement of the community in the disease prevention measures. As shown in Table 1, 825 respondents 
$(50.3 \%)$ stated that other members of the community warned those members that ignored restrictions and 525 or 32\% that everyone was allowed to do whatever they wanted; 290 respondents $(17.7 \%)$ stated not knowing or did not answer altogether.

Table 1: Community Involvement in Abidance of the Disease Control Measures

\begin{tabular}{|l|l|c|c|c|c|}
\hline \multirow{7}{*}{} & $\begin{array}{c}\text { Did the village/ neighbourhood get } \\
\text { involved in abidance of prevention } \\
\text { measures? }\end{array}$ & Frequency & $\begin{array}{c}\text { Percent } \\
(\%)\end{array}$ & $\begin{array}{c}\text { Valid } \\
\text { Percent } \\
(\%)\end{array}$ & $\begin{array}{c}\text { Cumulative } \\
\text { Percent } \\
(\%)\end{array}$ \\
\hline & $\begin{array}{l}\text { Yes, the village/ neighbourhood } \\
\text { inhabitants warned those that did } \\
\text { not abide by the prevention } \\
\text { measures }\end{array}$ & 825 & 50.3 & 61.1 & 61.1 \\
\cline { 2 - 6 } & $\begin{array}{l}\text { No, everyone was allowed to do } \\
\text { whatever they wanted }\end{array}$ & 525 & 32.0 & 38.9 & 100.0 \\
\cline { 2 - 6 } & Total & 1350 & 82.3 & 100.0 & \\
\hline Missing & Don't Know/No Answer & 290 & 17.7 & & \\
\hline Total & & 1640 & 100.0 & & \\
\hline
\end{tabular}

A third issue of interest for our study was the respondents' attitude towards the restrictions for collective events like weddings, baptisms and funerals. In agreement with the restrictions were 644 respondents $(39.3 \%)$, in partial agreement $684(41.7 \%)$ and in complete disagreement $254(15.5 \%)$ respondents; 58 respondents $(3.5 \%)$ did not know or did not answer. The data is depicted in Table 2.

Table 2: Approval Rating for Restrictions to Collective Events (weddings, baptisms, funerals)

\begin{tabular}{|l|l|c|c|c|c|}
\hline \multirow{7}{*}{ Valid } & $\begin{array}{c}\text { To what extent do you agree } \\
\text { with the restrictions concerning } \\
\text { collective events (weddings, } \\
\text { baptisms, funerals)? }\end{array}$ & Frequency & $\begin{array}{c}\text { Percent } \\
(\%)\end{array}$ & $\begin{array}{c}\text { Valid } \\
\text { Percent } \\
(\%)\end{array}$ & $\begin{array}{c}\text { Cumulative } \\
\text { Percent } \\
(\%)\end{array}$ \\
\cline { 2 - 6 } & I totally agree & 644 & 39.3 & 40.7 & 40.7 \\
\cline { 2 - 6 } & I partially agree & 684 & 41.7 & 43.2 & 83.9 \\
\cline { 2 - 6 } & I totally disagree & 254 & 15.5 & 16.1 & 100.0 \\
\hline Missing & Dotal & 1582 & 96.5 & 100.0 & \\
\hline Total & 58 & 3.5 & & \\
\hline
\end{tabular}

The analysis of the statistical association between the independent variables we considered (gender, age, living area, personal contamination, deceased in family and neighborhood) and some variables describing community social control reveals a series of interesting aspects which we will mention next.

The first finding is that gender-wise there are no significant differences in the perception of community control in general. Gender doesn't seem to be a factor of difference in the perception of community involvement in abidance by the disease control restrictions, or in attitudes on restrictions regarding collective events either. 
The age however appears to be more significant in perceptions and attitudes. In the case of social control, the very young (18 to 29 years old) and the very old (over $70 \mathrm{~s}$ ) appear to have a stronger perception of community control over members' lives $35.7 \%$ and $33.3 \%$ respectively), as opposed to the middle ages of 40 to 49 years old of $17.7 \%$ and the 60 to 69 years old of $14.8 \%$ respectively. The appreciation that the village/ neighborhood inhabitants got involved in the abidance of restrictive measures was high among the young $(68.7 \%)$, but lower $(47.2 \%)$ among the older than 69 . One could interpret this result as being partially due to a different perception of the age groups of being the target of control. In agreement with restrictions on collective events were $37.1 \%$ of the very young and $46 \%$ of the 60 to 69 years old. The other age categories found themselves in terms of attitude within the area laid out by the limits of the young and old categories. Regardless of being applicable to inside or outside events, the restrictions we refer to implied social distancing, the wearing of masks and limitations on the number of participants.

Although not as low as we expected, the perception of the village/neighborhood not having control over members' lives was lower in the rural than the urban space $(25.7 \%$ as opposed to $32.3 \%$ ). According to respondents' perception, in both cases the issue mostly controlled was abidance by the law. More so than in the urban areas, the respondents that lived in the rural areas during the pandemic warned about abidance of restrictions $(65.9 \%$ as opposed to $59.15 \%)$. In total agreement with restrictions on collective events (weddings, baptisms, funerals) were $32.3 \%$ of respondents that lived in rural areas during the pandemic and $43.8 \%$ of the respondents that lived in urban areas.

The personal experience with COVID-19 (infection, family loss, neighborhood loss) may be important for identifying explanations on attitudes towards restrictions on collective events. Our research reveals that the personal experience of COVID-19 disease doesn't necessarily mean being in accord with the imposed restrictions, the difference between those having contracted the virus and those that haven't being no larger than $2 \%$. The difference is of $7 \%$ in favor of those being in total agreement with the restrictions and have experienced the death of a loved one, but this difference regresses to less than two percentage points when one adds the partial agreement. A similar situation can be found among those that experienced the loss of a neighbor. See Table 3 .

Table 3: Persons Deceased among Neighbours and Agreement to Restrictions on Collective Events (weddings, baptisms, funerals) $(\mathrm{N}=1558)$

\begin{tabular}{|l|c|c|c|c|}
\hline & \multicolumn{2}{|c|}{$\begin{array}{c}\text { To what extent do you agree with the restrictions concerning } \\
\text { collective events (weddings, baptisms, funerals)? }\end{array}$} & Total \\
\hline \multirow{2}{*}{$\begin{array}{c}\text { Did you bave persons } \\
\text { deceased among your } \\
\text { neighbours? }\end{array}$} & Totally Agree & $\begin{array}{c}\text { Partially } \\
\text { Agree }\end{array}$ & Totally Disagree & \\
\hline Yes & 144 & 132 & 45 & 321 \\
\cline { 2 - 5 } & $44.9 \%$ & $41.1 \%$ & $14.0 \%$ & $100.0 \%$ \\
\hline No & 492 & 539 & 206 & 1237 \\
\cline { 2 - 5 } & $39.8 \%$ & $43.6 \%$ & $16.7 \%$ & $100.0 \%$ \\
\hline
\end{tabular}


To the extent that we have not seen the objective variables indicating significant differences in terms of attitude towards restrictions on collective events, we consider now appropriate the introduction of a subjective independent variable. Namely is the level of fear experienced by the respondents at the time of the survey.

As one can see in Table 4 respondents experiencing a high level of anxiety were $78 \%$ in total and partial agreement with the restrictions and those experiencing a moderate level of fear $89.6 \%$ in favor of the restrictions - as opposed to those experiencing no fear being $66.9 \%$ in agreement.

Table 4: Fear and Agreement to Restrictions on Collective Events (weddings, baptisms, funerals) $(\mathrm{N}=1575)$

\begin{tabular}{|l|c|c|c|r|}
\hline & \multicolumn{3}{|c|}{ To what extent do you agree with the restrictions concerning } & \multicolumn{1}{|c|}{$\begin{array}{c}\text { Total } \\
\text { collective events } \\
\text { (wveddings, baptisms, funerals)? }\end{array}$} \\
\hline $\begin{array}{l}\text { Is there some level of fear in } \\
\text { what you experience right } \\
\text { now? }\end{array}$ & Totally agree & Partially Agree & Total Disagree & \\
\hline Yes, very large & 59 & 51 & 31 & 141 \\
\cline { 2 - 5 } & $41.8 \%$ & $36.2 \%$ & $22.0 \%$ & $100.0 \%$ \\
\hline Yes, but moderate & 486 & 510 & 115 & 1111 \\
\cline { 2 - 5 } & $43.7 \%$ & $45.9 \%$ & $10.4 \%$ & $100.0 \%$ \\
\hline $\begin{array}{l}\text { No, I do not experience } \\
\text { any fear }\end{array}$ & 95 & 121 & 107 & 323 \\
\cline { 2 - 5 } & $29.4 \%$ & $37.5 \%$ & $33.1 \%$ & $100.0 \%$ \\
\hline
\end{tabular}

\subsection{Discussion}

The results of our research appear to indicate the existence of a relatively high level of social control in the community with a slight increase in rural communities. A strong area of similarities between the two types of communities appears to be the informal control over law abiding. This finding is relevant since most COVID-19 disease control restrictions are based on statutory law and not on community traditions norms. Within this context, based on respondents' answers, the informal social control was an encouraging phenomenon and was concentrated on warning those who were incline to ignore regulation. Collective events like weddings, baptisms and funerals are solidly rooted in community tradition and that may be why respondents' agreement to specific restrictions like social distancing, wearing of masks and the limitation of attendees is not always meeting majority. This aspect is even more visible in rural communities.

In regard to all aspects, gender is not a differentiating variable of either the perceptions or attitudes. Age more likely plays a role in its extremes (the very young and the very old). Another interesting observation is that the experience with COVID-19 (infection, family loss or neighborhood loss) doesn't necessarily imply agreement with restrictions on collective events. In this case also we believe the rooting of these events in 
12 | Community and social control during the COVID-19 pandemic

community traditions is an important contributing factor, but that would require more in-depth research.

The results of our research may constitute a good starting point for further understanding of community involvement in times of public health or other emergencies. Numerous studies undertaken during the debut of the pandemic suggest solutions to the problems of community involvement like steered processes, community engagement, community participation, the empowerment and community development. Bispo Junior and Brito Morais (2020) analysed three avenues via which the community participate in health action: community mobilization, community collaboration and community empowerment (Bispo Junior and Brito Morais, 2020, p. 3). In community mobilization the population's participation is limited to following health professionals' instructions. In community collaboration, "community participation is performed with the development of actions or services provision by community members". In this case also the need and actions are defined by professionals. Lastly "community empowerment aims to promote community development to change the population's living conditions with power-sharing between health systems and the population" (Bispo Júnior and Brito Morais, 2020, p. 4).

Renedo and Miles (2020) remind us that although the global health recommendations underlined the importance of community participation, the practical answers "have largely involved governments telling communities what to do, seemingly with minimal community inpue" (Marston, Renedo and Miles, p. 1676). Nevertheless, they warned us, communities can identify adequate solutions because: 1) they are aware of the information and rumors that circulate, 2) they can provide information on stigma and structural roadblocks and 3) they are well positioned to work with others in order to come up with collective answers. Each participation matters Marston, Renedo and Miles conclude "because unpopular measures risk. low compliance" (Marston, Renedo and Miles, 2020, p. 1676).

One question however is how can the community work be done in the pandemic restrictive environment of disease control? One answer to this question may be found in the concept of virtual communities. The availability of a voluntary base that proved effective during the COVID-19 pandemic may sustain the engagement or reengagement of people in digital forms of community life (Fisher et al., 2020, p. 248). The idea is also supported by Westoby and Harris who talk about community building in virtual space $(2020$, p. 554).

\section{Conclusions}

The literature on community during the pandemic is not only interesting, but also quite rich, virtually impossible to review in a single paper. Nevertheless, we believe we've managed to stress out the fact that both the roots of evil (new coronavirus spread) and those of good (disease control) can be found at community, rather than at the whole society level. The roots of evil may be curtailed by a reduction in inequities and the enlargement of social capital, and through the reduction in stigma and discrimination. Concurrently, the roots of good may be strengthen also through the consolidation of informal social control. Our research suggests that there is a solid foundation for the consolidation of social control in general and of that which is aimed at abidance of restrictions in rural space in particular. Certain age categories may be more active in this 
sense. Even if the experience of COVID-19 does not matter that much (infection, family loss, vicinity loss), the positive attitudes towards the collective protection measures appear encouraging. The existence of psychological premises like fear appears to have a larger contribution to the acceptance of restrictions than the sociodemographic variables. All of these we suggest, may constitute the basis for certain steered community processes and for the increase in the community engagement through capacitation and community development.

In relation to studies on informal social control our research could be continued and enriched through the inclusion of some already mentioned variables like community relationships, community attachment, or the perception of police effectiveness. Notwithstanding the major role the community can play in the pandemic disease control strategy, we feel the need to also warn though on the limits and the dangers of community intervention. The most effective way of verifying citizens' compliance, Kenny remarked, "is when fearful communities monitor themselves to ensure compliance with the new laws and regulations". Only that, by reporting violations, Kenny continued, "communities become part of the repressive state" (Kenny, 2020, p. 700). To that extent our appeal is not to transform community members into informers, but to intervene from one human to another as is happening in traditional social community control.

In a larger sense, the times of pandemic appear to suggest the need for a community reconfiguration. But is it enough? Kenny argues that it is necessary to exceed a simple reconfiguration of the community and achieve a radical reconfiguration of the whole society; there is no "return to normal" if the normal means what it was before. One is facing an emergency, Kenny suggested, because what happens as a response to the COVID-19 pandemic is "a rehearsal for the even bigger challenge for a humanity losing its way, climate change" (Kenny, 2020, p. 702).

\section{Acknowledgements}

This study was carried out as part of a research project at the Department of Social Sciences of the "1 Decembrie 1918" University of Alba Iulia.

\section{Funding}

The author received no financial support for the research, authorship, and/or publication of this article.

\section{Declaration of conflicting interests}

The author declares no conflicting interests. 
14 | Community and social control during the COVID-19 pandemic

\section{References}

Bispo Júnior, J. P. and Brito Morais, M. (2020). Community participation in the fight against COVID-19: between utilitarianism and social justice. Cadernos de Saúde Pública / Reports in Public Health, 36(8), https://doi.org/ 10.1590/0102-311x00151620

Borgonovi, F. and Elodie Andrieu, E. (2020). Bowling together by bowling alone: Social capital and COVID-19. Social Science \& Medicine, 265(113501), https://doi.org/10.1016/j.socscimed.2020.113501

Borgonovi, F., Andrieu, E. and Subramanian, S. V. (2020). Community-level social capital and COVID-19 infections and fatality in the US. VoxEU \& CEPR Coverage of the Covid-19 Global Pandemic, 22 July 2020, available at https://voxeu.org/article/community-level-social-capital-and-covid-19infections-and-fatality-us

Burchfield, K. B. (2009). Attachment as a source of informal social control in urban neighborhoods. Journal of Criminal Justice, 37(1), 45-54, https://doi. org/10.1016/j.jcrimjus.2008.12.007

Center, K. E., Da Silva, J., Hernandez, A. L., Vang, K., Martin, D. W., Mazurek, J., Lilo, E. A., Zimmerman, N. K., Krow-Lucal, E., Campbell, E. M., Cowins, J. V., Walker, C., Dominguez, K. L., Gallo1, B., Gunn, J. K. L., McCormick, D., Cochran, C., Smith, M. R., Dillaha, J. A., and James, A. E. (2020). Multidisciplinary Community-Based Investigation of a COVID-19 Outbreak Among Marshallese and Hispanic/Latino Communities - Benton and Washington Counties, Arkansas, March-June 2020. Morbidity and Mortality Weekly Report, US Department of Health and Human Services/Centers for Disease Control and Prevention, 69(48), 1807-1811, http://dx.doi.org/10.15585/mmwr.mm6948a2

Chopra, K. K. and Arora, V. K. (2020). Covid-19 and social stigma: Role of scientific community. The Indian Journal of Tuberculosis, 67(3), 284-285, https://doi.org/10.1016/j.ijtb.2020.07.012

Dubey, S., Biswas, P., Ghosh, R., Chatterjee, S., Dubey, M. J., Chatterjee, S., Lahiri, D., and Lavie, C. J. (2020). Psychosocial impact of COVID-19. Diabetes \& Metabolic Syndrome, 14 (5), 779-788, https://doi.org/10.1016/ j.dsx.2020.05.035

Erwin, C., Aultman, J., Harter, T., Illes, J. şi Rabbi Claudio J. Kogan, R. C. J. (2020). Rural and Remote Communities: Unique Ethical Issues in the COVID-19 Pandemic. The American Journal of Bioethics, 20 (7), 117-120, https://doi.org/10.1080/15265161.2020.1764139

Fisher, J., Languilaire, J.-C., Lawthom, R., Nieuwenhuis, R., Petts, R. J., Runswick-Cole, A, and Yerkes, M. A. (2020). Community, work, and 
family in times of COVID-19. Community, Work \& Family, 23(3), 247-252, https://doi.org/10.1080/13668803.2020.1756568

Gabriel, M. G., Brown, A., León, M., and Outley, C. (2020), Power and Social Control of Youth during the COVID-19 Pandemic. Leisure Sciences, https://doi.org/10.1080/01490400.2020.1774008

Harlem, G. (2020). Descriptive analysis of social determinant factors in urban communities affected by COVID-19. Journal of Public Health, 42(3), 466469, https://doi.org/10.1093/pubmed/fdaa078

Kaplan, H. S., Trumble, B. C., Stieglitz, J., Mendez Mamany, R., Gutierrez Cayuba, M., Moye, M. L., Alami, S., Kraft, T., Quispe Gutierrez, R., Copajira Adrian, R., Thompson, R. C., Thomas, G. S., Michalik, D. E., Eid Rodriguez, D., and Gurven, M. D. (2020). Voluntary collective isolation as a best response to COVID-19 for indigenous populations? A case study and protocol from the Bolivian Amazon. Public Health, 395(10238), $1727-$ 1734, https://doi.org/10.1016/S0140-6736(20)31104-1

Kenny, S. (2020). Covid-19 and community development. Community Development Journal, 5(4), 699-703, https://doi.org/10.1093/cdj/bsaa020

Marston, C., Renedo, A. and Miles, S. (2020). Community participation is crucial in a pandemic. The Lancet, 395(10238), 1676-1678, https://doi.org/ 10.1016/S0140-6736(20)31054-0

Pascaru, M. (2021). Cum trăim in pandemie? Raport rezultate preliminare [How do We Live During the Pandemic? Preliminary Results Report], January 2021, "1 Decembrie 1918" University of Alba Iulia, Alba Iulia, available at https://www.researchgate.net/publication/348564232_CUM_TRAIM_I N_PANDEMIE_HOW_DO_WE_LIVE_DURING_THE_PANDEMI C? channel $=$ doi\&linkId $=600529 \mathrm{e} 5 \mathrm{a} 6 \mathrm{fdccdcb} 8609794 \&$ showFulltext $=$ true

Peters, D. J. (2020). Community Susceptibility and Resiliency to COVID-19 Across the Rural-Urban Continuum in the United States. The Journal of Rural Health, 36 (3), 446-456, https://doi.org/10.1111/jrh.12477

Sakellarides, C. (2020). From Viral City to Smart City: Learning from Pandemic Experiences. Acta Medica Portuguesa, 33(6), 359-361, https://doi.org/ 10.20344/amp.13841

Sargeant, E., Murphy, K., McCarthy, M., and Williamson, H. (2021). The Formal-Informal Control Nexus During COVID-19: What Drives Informal Social Control of Social Distancing Restrictions During Lockdown? Crime \& Delinquency, First Published February 3, 2021, https://doi.org/10.1177/0011128721991824

Silver, E. and Niller, L.L. (2006). Sources of Informal Social Control in Chicago Neighborhoods. Criminology, 43 (2), 551-584, https://doi.org/10.1111/ j.1745-9125.2004.tb00529.x 
16 | Community and social control during the COVID-19 pandemic

Sneed, R. S., Key, K., Bailey, S., and Johnson-Lawrence, V. (2020). Social and psychological consequences of the COVID-19 pandemic in African-American communities: Lessons from Michigan. Psychological Trauma: Theory, Research, Practice, and Policy, 12(5), 446-448, https://doi.org/10.1037/tra0000881

Vélez, M. B. (2001). The Role of Public Social Control in Urban Neighborhoods: A Multilevel Analysis of Victimization Risk. Criminology, 39(4), 837-864, https://doi.org/10.1111/j.1745-9125.2001.tb00942.x

Warner, B.D. and Rountree, P.W. (1997). Local Social Ties in a Community and Crime Model: Questioning the Systemic Nature of Informal Social Control. Social Problems, 4 (4), 520-536, https://doi.org/10.2307/3097221

Westoby, P. and Harris, V. (2020). Community development 'yet-to-come' during and post the COVID-19 pandemic: from Derrida to Zuboff. Community Development Journal, 55(4), 553-569, https://doi.org/10.1093/ $\mathrm{cdj} / \mathrm{bsaa026}$

World Health Organization (2020). Risk communication and community engagement readiness and response to coronavirus disease (COVID-19), 19 March 2020, available at https://apps.who.int/iris/handle/10665/331513

Wickes, R., Hipp, J., Sargeant, E., and Mazerolle, L. (2017). Neighborhood Social Ties and Shared Expectations for Informal Social Control: Do They Influence Informal Social Control Actions? Journal of Quantitative Criminology, 33(1), 101-129, https://doi.org/10.1007/s10940-016-9285-x

Zhu, J. and Cai, Y. (2020). Engaging the communities in Wuhan, China during the COVID-19 outbreak. Global Health Research and Policy, 5 (35), https://doi.org/ $10.1186 / \mathrm{s} 41256-020-00162-3$ 